\title{
Características das emissões otoacústicas por transientes em programa de triagem auditiva neonatal $* * * * *$
}

\author{
Characteristics of transient evoked otoacoustic emissions in \\ newborn hearing screening program
}

\author{
Alessandra Spada Durante* (asdurant@usp.br) \\ Renata Mota Mamede Carvallo** \\ Fabiana Sanches da Costa*** \\ Jordana Costa Soares $* * * *$
}

\begin{abstract}
*Fonoaudióloga. Doutora em Ciências pela Faculdade de Medicina da Universidade de São Paulo (FMUSP). Professora Assistente do Curso de Fonoaudiologia da Faculdade de Ciências Médicas da Santa Casa de São Paulo.

**Fonoaudióloga. Professora LivreDocente Associada do Curso de Fonoaudiologia da FMUSP.

***Fonoaudióloga. Bolsista de Capacitação Técnica pela Fundação de Amparo à Pesquisa do Estado de São Paulo (Fapesp).

****Fonoaudióloga. Bolsista de Capacitação Técnica pela Fapesp.

*****Trabalho Realizado no Hospital Universitário da USP
\end{abstract}

Artigo de Pesquisa

Artigo Submetido a Avaliação por Pares

Conflito de Interesse: não

\begin{abstract}
Background: otoacoustic emissions (OAE) are considered the main instrument of the Newborn Hearing Screening Program (NHSP). Aim: to analyze the OAE of newborns evaluated in the NHSP. Method: transient evoked OAE recordings were captured in 1000 infants. The data were analyzed using the analysis of multivaried variance (Manova). Results: reference tables were calculated for the over all OAE levels and for frequency bands, according to gender and ear. The duration of the exam in the nursery was shorter than in the clinic. Conclusion: The level of the OAE was influenced by gender and ear, except for $0,7 \mathrm{kHz}$. However, there were no observed differences between neonates without and with auditory risk.
\end{abstract}

Key Words: Infant; Risk Factors; Otoacoustic Emissions; Spontaneous.

\section{Resumo}

Tema: as emissões otoacústicas (EOA) são consideradas como o principal método dos programas de triagem auditiva neonatal (PTAN). Objetivo: analisar as EOA de neonatos avaliados em PTAN. Método: foi realizada captação das EOA por transiente em 1000 lactentes. Os dados foram analisados por modelo de análise de variância multivariada (Manova). Resultados: foram calculadas tabelas de referência para os níveis das EOA geral e por banda de freqüência, segundo o gênero e a orelha. A duração do exame na maternidade foi menor do que no ambulatório. Conclusão: o nível das EOA foi influenciado pelo gênero e orelha, exceto para $0,7 \mathrm{kHz}$, porém não foi observada diferença entre as respostas dos neonatos sem e com risco auditivo.

Palavras-Chave: Lactente; Fatores de Risco; Emissões Otoacústicas Espontâneas. 


\section{Introduction}

One of the most fascinating audiology discoveries, in the last years, certainly was the understanding of the cochlea active mechanisms (Davis, 1983).

The otoacoustic emissions (OAE) reflect the active and micromechanical proprieties of the organ of Corti (Kemp,2002), and the outer hair cells (OHC) seem to be particularly involved in their generation (Dallos; He, 2000). The transient evoked otoacoustic emissions (TEOAE), one way to evoke OAE, recording occurs when the ear is stimulated with a very short but strong broadband stimulus (click). The procedure is non-invasive, quick, applicable in a non-soundproof area, objective (it doesn't depend of individual response), and with a level of sensitivity from mild to profound hearing loss, uni or bilateral.

The OAE presence indicate that the preneural cochlear receptor mechanism (and necessarily the middle ear mechanism as well) is able to respond to sound in a normal way, indicating healthy cochlear status. The discovery of OAE and of the proper technique to register the signals fit the need of testing a great number of neonates.

According to national and international organizations about infant hearing (JCIH,2000; CBPAI,2001) 30 to $50 \%$ of child with significant hearing loss have never exhibited any of the risk factors, thus the hearing screening is recommended to all neonate and the TEOAE is an useful procedure to be used at neonatal population.

White; Behrens (1993) with the Rhode Island Hearing Assessment Project, developed the first large scale clinic experiment with TEOAE in the USA. In normal nurseries and in intensive care units the prevalence of sensorineural hearing loss was 1.5 to 5.95 per 1000 neonates. The results of the Rhode Island Project have enhanced the need of universal hearing screening, before the neonate leaves the hospital.

Despite the fact that this procedure is internationally recognized as the most promising for neonatal hearing screening, large scale national studies are necessary to determine the characteristics of TEOAE, in order to establish some useful criteria in deciding if TEOAE could be considered as normal or altered in a screening test, with a greater power of decision. Thus, the present study has the purpose to determine the characteristics of TEOAE in neonates tested in a universal hearing screening program in a university hospital of Sao Paulo.

\section{Methods}

\section{Population of study}

For this study, 1000 neonates with born at University Hospital Nursery - USP, between March 10 and July 8 of 2003 were evaluated, 887 without risk factor for hearing loss (455 males and 432 females) and 113 neonates with at least one risk factor for hearing loss (JCIH, 2000), 56 males and 57 females.

The inclusion criterion selected the neonates with presence of TEOAE with general reproducibility ${ }^{3} 50 \%$, reproducibility specific on higher frequencies $>70 \%$ and stability $370 \%$.

\section{Equipment}

. ILO 292 / ECHOPORT PLUS - Otodynamics Analyser - which allows the recording of TEOAE - Portable computer KDS, with Pentium III processor and colored monitor, in which is installed the ILO 292 version 5.61.

\section{Procedure}

The study was approved by the HU-USP ethics committee (291/02). Written informed consent was obtained from the parent or guardian of each neonate tested in this study. The anamneses registered data related to health during the gestational and neonatal period, and the family communication aspects (hearing and language). The risk factors for hearing loss were registered.

The neonate was positioned in normal cradle, preferable while they were naturally asleep, and the TEOAE probe was adapted on external ear, with an soft latex olive. Half of the tests were initiated by the right ear and the other half by the left ear.

The hearing screening at the nursery occurred between 48 and 60 hours of age during the admission on nursery or mother and child's ward from Monday to Friday. The neonates discharged from hospital on weekend or holidays and who were not tested for hearing loss were referred to clinical screening in 2 to 8 weeks of age (Durante et al., 2003; 2004a; 2004b).

It was used broadband stimulus click (transient) with intensity of $78-83 \mathrm{~dB}$ peak, non linear mode, eliminating the occurrence of artifacts, and allowing the clinical application of the experiment. Besides, the quickscreen mode, indicated to neonatal screening, was selected. The TEOAE were collected until 50 quiet sweeps were recorded in each ear and 
the other parameters of inclusion were achieved.

\section{Statistics}

For each experimental unity the following explicative data were registered: conceptional age, gender, prenatal and perinatal problems, risk for hearing loss, site of the screening (nursery or clinic).

And the following response data for each ear: TEOAE response level and per frequency bandwidths $(0.7 ; 1.5 ; 2.2 ; 3.0 ;$ e $3.7 \mathrm{kHz})($ in $\mathrm{dB})$, and the test time duration (in seconds).

The statistical analyses were realized with the "Centro de Estatística Aplicada do Instituto de Matemática e Estatística da Universidade de São Paulo (CEA-IME USP)".

A model of analysis of multivaried variance (MANOVA) was adjusted to the TEOAE level and to the duration of the examination. The residual graphic analysis showed that for all models, the suppositions were satisfied (Barroso et al., 2003).

\section{Results}

This study presents the TEOAE median level collected in a great number of infants, what allowed the calculation of tables of reference for the OAE levels for the response and for frequency bands. There were no differences between the responses of : neonates with or without risk for hearing loss, term or premature birth, or neonates with or without pre and perinatal problems ( $\mathrm{p}>0.17)$.

For the $0.7 \mathrm{kHz}$ frequency band the gender was not significant (gender $\mathrm{p}=0.203$ ) so the percents were calculated just for each ear (Table 1). For the other frequency bandwidth and for the response the percents were calculated according to gender and ear, once both were significant $(\mathrm{p}<0.01)$ (Tables 2 to 5).

In addition, the duration of the examination per ear was analyzed according to the infant's age at the moment of the screening. The data analysis showed that the duration of the examination varied according to the site where the screening was performed $(p<0.001)$, e.g. the time was shorter when the screening was performed at the nursery (ages 1 to 6) compared to the clinic (ages 7 and 8) (Graphic 1).

TABLE 1. Percents of TEOAE level for the $0.7 \mathrm{kHz}$ frequency bandwidth, per ear.

\begin{tabular}{cc|ccccccc} 
Orelha & $\mathrm{N}$ & $5 \%$ & $10 \%$ & $25 \%$ & $50 \%$ & $75 \%$ & $90 \%$ & $95 \%$ \\
\hline direita & 360 & 0 & 0,00 & 0,58 & 2,87 & 5,17 & 7,23 & 8,47 \\
esquerda & 342 & 0 & 0,00 & 0,70 & 2,66 & 4,62 & 6,39 & 7,45 \\
\hline
\end{tabular}

TABLE 2. Percents of TEOAE level for males right ear, per frequency bandwidth.

\begin{tabular}{cccccccccc} 
& & \multicolumn{9}{c}{ Percentis } & & & \\
Freqüência & $\mathrm{N}$ & $5 \%$ & $10 \%$ & $25 \%$ & $50 \%$ & $75 \%$ & $90 \%$ & $95 \%$ \\
\hline resposta geral & 511 & 11,09 & 13,14 & 16,58 & 20,39 & 24,21 & 27,64 & 29,70 \\
$1,5 \mathrm{khz}$ & 431 & 1,83 & 4,14 & 8,00 & 12,29 & 16,58 & 20,44 & 22,75 \\
$2,2 \mathrm{kHz}$ & 438 & 6,04 & 8,24 & 11,90 & 15,97 & 20,04 & 23,70 & 25,89 \\
$3,0 \mathrm{kHz}$ & 437 & 5,76 & 8,09 & 12,00 & 16,33 & 20,66 & 24,57 & 26,90 \\
$4,0 \mathrm{kHz}$ & 440 & 4,85 & 7,28 & 11,35 & 15,87 & 20,39 & 24,45 & 26,88 \\
\hline
\end{tabular}


TABLE 3. Percents of TEOAE level for males left ear, per frequency bandwidth

\begin{tabular}{|c|c|c|c|c|c|c|c|c|}
\hline \multirow[b]{2}{*}{ Freqüência } & \multirow[b]{2}{*}{$\mathrm{N}$} & \multicolumn{7}{|c|}{ Percentis } \\
\hline & & $5 \%$ & $10 \%$ & $25 \%$ & $50 \%$ & $75 \%$ & $90 \%$ & $95 \%$ \\
\hline resposta geral & 511 & 10,07 & 12,15 & 15,62 & 19,47 & 23,33 & 26,80 & 28,87 \\
\hline $1,5 \mathrm{kHz}$ & 425 & 1,56 & 3,85 & 7,68 & 11,93 & 16,18 & 20,00 & 22,29 \\
\hline $2,2 \mathrm{kHz}$ & 439 & 6,27 & 8,46 & 12,12 & 16,18 & 20,25 & 23,90 & 26,09 \\
\hline $3,0 \mathrm{kHz}$ & 439 & 5,87 & 8,14 & 11,93 & 16,14 & 20,36 & 24,15 & 26,42 \\
\hline $4,0 \mathrm{kHz}$ & 440 & 4,76 & 7,14 & 11,12 & 15,54 & 19,96 & 23,94 & 26,32 \\
\hline
\end{tabular}

TABLE 4. Percents of TEOAE level for females right ear, per frequency bandwidth.

\begin{tabular}{|c|c|c|c|c|c|c|c|c|}
\hline \multirow[b]{2}{*}{ Freqüência } & \multirow[b]{2}{*}{$\mathrm{N}$} & \multicolumn{7}{|c|}{ Percentis } \\
\hline & & $5 \%$ & $10 \%$ & $25 \%$ & $50 \%$ & $75 \%$ & $90 \%$ & $95 \%$ \\
\hline resposta geral & 487 & 12,76 & 14,82 & 18,25 & 22,07 & 25,88 & 29,32 & 31,37 \\
\hline $1,5 \mathrm{kHz}$ & 416 & 2,86 & 5,17 & 9,03 & 13,32 & 17,60 & 21,46 & 23,77 \\
\hline $2,2 \mathrm{kHz}$ & 422 & 7,36 & 9,56 & 13,22 & 17,29 & 21,36 & 25,02 & 27,21 \\
\hline $3,0 \mathrm{kHz}$ & 421 & 6,52 & 8,85 & 12,75 & 17,09 & 21,42 & 25,32 & 27,66 \\
\hline $4,0 \mathrm{kHz}$ & 426 & 6,52 & 8,96 & 13,02 & 17,54 & 22,06 & 26,12 & 28,56 \\
\hline
\end{tabular}

TABLE 5. Percents of TEOAE level for females left ear, per frequency bandwidth.

\begin{tabular}{ccccccc|ccc} 
Freqüência & $\mathrm{N}$ & $5 \%$ & $10 \%$ & $25 \%$ & $50 \%$ & $75 \%$ & $90 \%$ & $95 \%$ \\
\hline resposta geral & 486 & 11,72 & 13,79 & 17,26 & 21,12 & 24,97 & 28,44 & 30,52 \\
$1,5 \mathrm{kHz}$ & 415 & 1,98 & 4,27 & 8,10 & 12,35 & 16,60 & 20,42 & 22,71 \\
$2,2 \mathrm{kHz}$ & 421 & 6,56 & 8,75 & 12,40 & 16,47 & 20,53 & 24,19 & 26,38 \\
$3,0 \mathrm{kHz}$ & 422 & 6,85 & 9,12 & 12,91 & 17,12 & 21,34 & 25,13 & 27,40 \\
$4,0 \mathrm{kHz}$ & 422 & 6,55 & 8,93 & 12,90 & 17,32 & 21,74 & 25,72 & 28,10 \\
\hline
\end{tabular}

\section{Discussion}

In this paper the TEOAE showed larger levels in females and right ears, this fact was also observed by other authors (Table 6), reinforcing that the hearing sensitivity is stronger in females and right ears (Kannan et al., 1974) and that this gender differences emerge early in development. The higher OHC count in females (Wright et al., 1987), gender with a higher prevalence of OAE (Cassidy; Ditty, 2001). The spontaneous otoacoustic emissions (SOAE) are found in the absence of acoustic stimulation, and are also more prevalent in females and right ears, and despite the uncertain clinical application their presence have impact on TEOAE measure (Probst et al., 1986). These gender differences could account for the TEOAE higher level observed in females, and the fact that maximum cochlear length is already achieved at birth enables that these gender differences could be observed on neonatal period.

In Brazil, Fuzetti (2002) studied the occurrence 
GRAPHIC 1. TEOAE test median duration (in seconds) by ear and age.

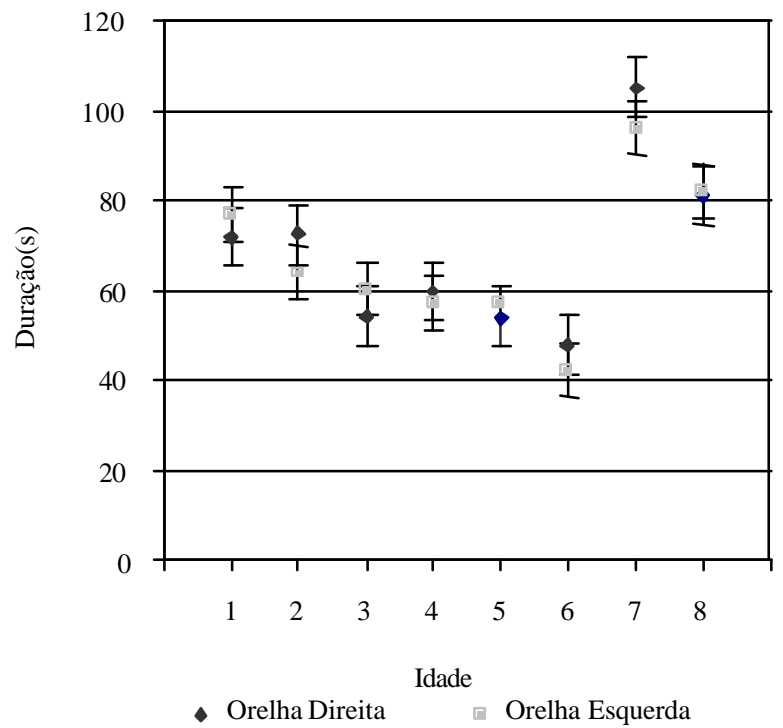

Legend for the infant age:

Idade

\begin{tabular}{cc}
\hline 1 & $>24 \mathrm{~h}<36 \mathrm{~h}$ \\
2 & $>37 \mathrm{~h}<48 \mathrm{~h}$ \\
3 & $>49 \mathrm{~h}<60 \mathrm{~h}$ \\
4 & $>61 \mathrm{~h} \mathrm{e}<72 \mathrm{~h}$ \\
5 & até 10 dias \\
6 & $>10$ dias sem alta prévia \\
7 & Ambulatório 2-4 semanas \\
8 & Ambulatório 5-8 semanas \\
\hline
\end{tabular}

TABLE 6 . TEOAE level in neonates according gender, ear and author.

\begin{tabular}{c|c|c|c|c}
\multirow{2}{*}{ Autor } & \multicolumn{4}{|c}{ Nível das EOAT - dB NPS } \\
\cline { 2 - 5 } & Feminino & Masculino & OD & OE \\
Aidan et al. (1997) & 22,1 & 21,4 & 22,4 & 21,1 \\
Newmark et al. (1997) & 23 & 21,5 & 22 & 21 \\
Basseto (1998) & 13,5 & 13 & 13,7 & 12,9 \\
Durante (2000) & 17,7 & 16,3 & 17,7 & 16,2 \\
Durante (2004) & 17,9 & 16,6 & 17,9 & 16,5 \\
Presente estudo & 21,6 & 19,9 & 21,2 & 20,3 \\
\hline
\end{tabular}

of SOAE and TEOAE in 52 neonates. The author observed the occurrence of SOAE in $78 \%$ of the right ears and $66.7 \%$ of the left ears. Besides, there was a significant $(\mathrm{p}<0.010)$ statistical difference between the TEOAE level medians on the ears that presented the SOAE and those that did not, and the ears with SOAE revealed stronger response levels.

Soares et al. (1998) observed the occurrence of SOAE in $52.4 \%$ of females and in $27.5 \%$ of males, and the stronger TEOAE response levels were collected in frequencies with presence of SOAE in $63.6 \%$ of time.

On the other hand, the difference observed between ears, usually associated with a right-ear sensitivity advantage and the left-hemispheric advantage in speech perception and language function (Previc, 1991), has been recently associated with the auditory efferent control (Newmark,1997). Studies done by Khalfa et al. (1998) in adults and by Morlet et al. (1999) and Durante (2004) in neonates, have shown that the TEOAE suppression effect is stronger on right ears providing evidence that the efferent activity is asymmetric between the ears, and reinforces the acoustic signal detection on the presence of competitive noise on the right ear. Thus either the TEOAE suppression effect or the TEOAE level constitute valid and independent markers of peripheral auditory lateralization. The two markers reflect specific mechanisms with no apparent link, and their asymmetries are not related. Thus, the lateralization of $\mathrm{OHC}$ motility as reflected by TEOAE does not influence the asymmetry in OHC active mechanisms efferent regulation (Khalfa et al., 1998).

Another significant aspect presented by this paper was the distinction between the time necessary to record TEOAE in infants at the nursery and at the clinic. The mean duration time is similar to the observed at the literature (Table 7), however as in Kok et al.(1994) study at the nursery the test was faster, this is probable associated to the infant state, because at the clinic the infants are more often awake and restless the test would take longer. At the nursery because of the infants hospitalization it is possible to perform the test at the natural sleep, and how nearest from the discharge faster is the examination (Graphic 1), Korres et al. (2003) reported similar findings at the growth of OAE during the first days postpartum.

It is important to notice that the TEOAE response level in infants with risk for hearing loss was not different from the response in infants without risk. Also was no difference between the 
TEOAE response level from mother's infants with or without conceptional problems, and between the infants with or without perinatal problems. And finally it was not find differences between the TEOAE response level from term or premature groups, suggesting that at birth the $\mathrm{OHC}$ functional maturity is completed. These results are similar to the findings reported in Garcia et al. (2002), that could collect TEOAE in neonates from at least 27 weeks of conceptional age. So this paper presents results that do not differ from the international literature (Norton et al., 2000; Cone-Wesson et al., 2000) and suggest that the neonatal hearing screening pass/fail criterion, for TEOAE protocol, could be universal.

When compared to the other frequency bands the $0.7 \mathrm{kHz}$ presented the smallest response level, smaller than $9 \mathrm{~dB}$ at 95 percent of all trials (Table 1), what has been usually justified by the physiologic noise, characteristic of this age (Kemp, 2002).

At $1.5 \mathrm{kHz}$ frequency band only $5 \%$ of neonates presented response level smaller than $3 \mathrm{~dB}$ for both ears and for both genders, illustrating that a minority show low response levels at this frequency band (Tables 2 to 5 ).

However, the higher frequency band (2.2, $3.0 \mathrm{e}$ $3.7 \mathrm{kHz}$ ) showed response levels with larger medians, $15 \mathrm{~dB}$ for males and $17 \mathrm{~dB}$ for females. The response was larger than $10 \mathrm{~dB}$ in $95 \%$ of the studied neonates, for both ears and for both genders, what agrees with papers that found TEOAE from $15 \mathrm{~dB}$ to levels greater than $30 \mathrm{~dB}$ (Kemp, 2002). In this work $10 \%$ of the infants showed response levels greater than $27 \mathrm{~dB}$, for both genders (Tables 2 to 5).

TABLE 7. TEOAE test bilateral median duration (in seconds) in infants according author.

\begin{tabular}{c|c} 
Autor & Duração do Exame de EOA(s) \\
Aidan et al. (1997) & 89 \\
Paludetti et al. (1999) & 98 \\
Norton et al. (2000) & 120 \\
Raineri1 et al. (2001) & 82 \\
presente estudo - maternidade & 90 \\
presente estudo - ambulatório & 180 \\
\hline
\end{tabular}

\section{Conclusions}

The study allowed the elaboration of TEOAE analysis reference tables which can be used for population with the same characteristics of the studied sample.

The TEOAE level was influenced by gender and ear, except for $0.7 \mathrm{kHz}$, however there was no differences between the responses from neonates with and without risk factor for hearing loss, allowing the adopting of universal pass/fail criterion. Besides, the screening should be done preferable at the nursery, site that allows a shorter time test. 
Acknowledgments: To Dr. Ana Luiza Navas for revising the English version of this study.

To Foundation for the Support of Research in the state of Sao Paulo (FAPESP - Grant 01/09605-5) for the financial We are also grateful to the staff of the University of Sao Paulo Institute of Mathematics and Statistics - Center for Statistics assistance.

\section{References}

AIDAN, D.; LESTANG, P.; AVAN, P.; BONFILS, P. Characteristics of transient evoked otoacoustic emissions (TEOEs) in neonates. Acta Otolaryngol., v. 117, n. 1, p. 25-30, 1997.

BARROSO, L. P.; SIMIDU, A. Y.; GIROLDO, F. R. S. Relatório de análise estatística sobre o projeto: programa de triagem auditiva neonatal do hospital universitário USP (RAE - CEA - 03P19). São Paulo: IME - USP, 2003.

BASSETO, M. C. A. Emissões otoacústicas evocadas transientes: estudo da amplitude de resposta em recémnascidos a termo e pré-termo. 1998. $211 \mathrm{f}$. Tese (Doutorado em Distúrbios da Comunicação Humana) - Universidade Federal de São Paulo, São Paulo.

CASSIDY, J. W.; DITTY, K. M. Gender differences among newborns on a transient evoked otoacoustic emissions test for hearing. J. Music Therapy, v. 38, n. 1, p. 28-35, 2001.

COMITÊ BRASILEIRO SOBRE PERDAS AUDITIVAS NA INFÂNCIA (CBPAI) - PERÍODO NEONATAL. J. Pediatr, Rio J., 2001. p.77-81.

CONE-WESSON, B.; VOHR, B. R.; SININGER, Y. S.; WIDEN, J. E.; FOLSON, R. C.; GORGA, M. P.; NORTON, S. J. Identification of neonatal hearing impairment: infants with hearing impairment. EarHear., v. 21, n. 5, p.488-507, 2000.

DALLOS, P.; HE, D. Z. Two models of outer hair cells stiffness and motility. Jaro, v. 1, n. 4, p. 283-291, 2000.

DAVIS, H. An active process in cochlear mechanics. Hear. Res., v. 9, n. 1, p. 79-90, 1983.

DURANTE, A. S. Supressão das emissões otoacústicas por transientes em neonatos com risco para alteração auditiva. 2004. 136 f. Tese (Doutorado em Ciências) Faculdade de Medicina, Universidade de São Paulo, São Paulo.

DURANTE, A. S. Estudo da amplitude das emissões otoacústicas evocadas transitórias com ruído contralateral em lactentes. 2000. 115 f. Dissertação (Mestrado em Ciências) - Faculdade de Medicina, Universidade de São Paulo, São Paulo.

DURANTE, A. S.; CARVALLO, R. M. M.; COSTA, M. T. Z.; CIANCIARULLO, M. A.; VOEGELS, R. L.; TAKAHASHI, G M.; SOARES, A. V. N.; SPIR, E. G Programa de triagem auditiva neonatal - modelo de implementação. Arq. Otorrinolaringol., v. 8, n. 1, p. 56-62, 2004a.
DURANTE, A. S.; CARVALLO, R. M. M.; COSTA, M. T. Z.; CIANCIARULlO, M. A.; VOEGELS, R. L.; TAKAHASHI, G M.; SOARES, A. V. N.; SPIR, E. G A implementação de programa de triagem auditiva neonatal universal em um hospital universitário brasileiro. Pediatria, São Paulo, v. 26, n. 2, p.78-84, 2004b.

DURANTE, A. S.; CARVALLO, R. M. M.; COSTA, M. T. Z.; CIANCIARULLO, M. A.; VOEGELS, R. L.; TAKAHASHI, G. M.; SOARES,A. V. N.; SPIR, E. G Triagem auditiva neonatal - justificável possível e necessária. Rev. Bras. Otorrinolaringol. (Caderno de Debates), v. 69, n. 2, p. 11-18, 2003.

FUZETTI, C.; LEWIS, D. R. Emissões otoacústicas espontâneas e evocadas por estímulo transiente em recémnascidos. Pró-Fono Revista de Atualização Científica, v. 15, n. 2, p. 189-198, 2003.

GARCIA, C. F. D.; ISAAC, M. L.; OLIVEIRA, J. A. A. Emissões otoacústicas evocadas transitórias: instrumento para a detecção precoce de alterções auditivas em recémnascidos a termo e pré-termo. Rev. Bras. Otorrinolaringol., v. 68, n. 3, p. 344-352, 2002.

JOINT COMMITTEE ON INFANT HEARING (JCIH), 2000. Position statement. Disponível em: 〈http:// www.audiology.org/professional/positions/jcih-early.php>. Acesso em: 18 ago. 2004.

KANNAN, P. M.; LIPSCOMB, D. M. Bilateral hearing asymetry in a large population. J. Acoust. Soc. Am., v. 55, n. 5, p. 1092-1094, 1974.

KHALFA, S.; MYCHEYL, C.; VEUILLET, E.; COLLET, L. Peripheral auditory lateralization assessment using TEOAEs. Hear. Res., v. 121, n. 1-2, p. 29-34, 1998.

KEMP, D. T. Otoacustic emissions, their oringinin cochlear function, and use. Br. Med. Bull., v. 63, n. 1, p. 223-241, 2002.

KOK, M. R.; ZANTEN, G. A.; BROCAAR, M. P.; JONGEJAN, H. T. M. Click-evoked oto-acoustic emissions in very-low-birth-weigth infants: a cross-sectinal data analysis. Audiology, v. 33, n. 3, p. 152-164, 1994.

KORRES, S.; NIKOLOPAULOS, T.; FEREKIDIS, E.; GOTZAMANOGLOU, Z.; GEORGIOU, A.; BLALATSOURAS, D. G. Otoacoustic emission in universal hearing screening: which day after birth should we examine the newborns? J. Oto-Rhino-Laryngol. \& Special., v. 65, n. 4, p. 199-201, 2003 
MORLET, T.; GOFORTH, L.; HOOD, L. J.; FERBER, C.; DUCLAUX, R.; BERLIN, C. I. Development of human cochlear active mechanism asymmetry: involvement of the medial olivocochlear system. Hear. Res., v. 134, n. 1-2, p. 153-162, 1999.

NEWMARK, M.; MERLOB, P.; BRESLOFF, I.; OLSHA, M.; ATTIAS, J. Click evoked otoacoustic emissions interaural and gender differences in newborns. J. Basic Clin. Physiol. Pharmacol., v. 8, n. 3, p. 133-139, 1997.

NORTON, S. J.; GORGA, M. P.; WIDEN, J. E.; VOHR, B. R.; FOLSOM, R. C.; SININGER, Y. S.; CONE-WESSON, B.; FLETCHER, K. A. Identification of neonatal hearing impairment: transient evoked otoacoustic emissions during the neonatal period. Ear Hear., v. 21, n. 5, p. 425-442, 2000 .

PALUDETTI, G; OTTAVIANI, F; FETONI, A. R.; ZUPPA, A. A.; TORTOROLO, G Transient evoked otoacoustic emission (TEOAEs) in newborns: normative data. Hear. Res., v. 47, n. 3, p. 235-241, 1999.

PREVIC, F. H. A general theory concerning the prenatal origins of cerebral lateralization in humans. Pysychol. Rev., v. 98, n. 3, p. 299-334, 1991.
PROBST, R.; COATS, A. C.; MARTIN, G. K.; LONSBURYMARTIN, B. L. Spontaneous click and tone-burst evoked otoacoustic emissions from normal ears. Hear. Res., v. 21, n. 3, p. 261-275, 1986.

RAINERI, G G; COUBE, C. Z. V.; COSTA FILHO, O. A.; ALVARENGA, K. F. Emissões otoacústicas evocadas produto de distorção em neonatos audiologicamente normais. Rev. Bras. Otorrinolaringol., v. 67, n. 5, p. 644-648, 2001.

SOARES, E.; ARTETA, L. M. C.; LOURENÇO, M. H. Análise da ocorrência de emissões otoacústicas espontâneas e sua correlação com as emissões otoacústicas transientes. In: ENCONTRO INTERNACIONAL DE AUDIOLOGIA, 13., 1998, Bauru, Anais... São Paulo: USP, 1998.

WHITE, K. R.; BEHRENS, T. R. Universal newborn hearing screening using transient evoked otoacoustic emissions: results of the Rhode Island hearing assessment project. Semin. Hear., v. 14, n. 1, p. 18-29, 1993.

WRIGHT, A.; DAVIS, A.; BREDBERG, G.; ULEHLOVA, L.; SPENCER, H. Hair cell distributions in the normal human cochlea. A report of a European working group. Acta Otolaryngol. (Stockholm), v. 436, p. 15-24, 1987. 